MANOUSOS E. KAMBOURIS

The Association of Historical Studies

KORYVANTES

Athens, Greece

E-mail: mekambouris@yahoo.com

SPYROS BAKAS

The Association of Historical Studies

KORYVANTES

Athens, Greece

E-mail: koryvanteshoplites@gmail.com
904:799.32(38)

COBISS.SR-ID 254102284

Original research article Received: January 29 2017

Accepted: October 31 $1^{\text {st }} 2017$

\title{
ARCHERY IN ANCIENT GREECE: OPERATIONAL PRACTICE AND TACTICS
}

\begin{abstract}
The issue of ancient Greek archery looms in mist, as it passed to history as a distrusted weapon, alien to the codes of honorable battle. Though, it had been kept in high respect. There was a full tactical and technical doctrine, as both literary and representational sources testify. Starting from Hercules, son of Zeus proper and demi-god and hero par excellence in the Greek lore, he is mentioned to shoot at point targets with great accuracy and at extended range with venomous arrows. Other known archers of the era are Odysseus and the non-Greek Paris, who is the most prominent; whole contingents though are mentioned as archer bodies and shoot over the first lines of the friendly formations. After this period of lords and soldiers trained to the bow, the classical Greeks use solid bodies of archers. They are few and mostly conscripted or imported by tyrants and other despised rulers. But although despised, whole areas are proficient with the bow and engulf its culture and the weapon is used with surgical accuracy against the prominent archer invader, Persia, with calamitous effect in both land and sea. The shooting technique and tactics of the era imply direct shots, but indirect, high-arc aiming is also mentioned some decades later as a known skill. By the time of Alexander, a standard doctrine which includes small but picked archer forces (losing their commanders thrice in 3 years) indicates their effectiveness in maneuver warfare over difficult terrain and in special operations.
\end{abstract}

\section{KEYWORDS: ARCHERY, ANCIENT GREECE, THE BRONZE AGE, THE ARCHAIC ERA, THE CLASSICAL} ERA.

\section{INTRODUCTION}

The issue of ancient Greek archery looms in mist, as it passed to history as a distrusted weapon, alien to the codes of honorable battle. The most famous ancient warriors, the Mycenaean era Achilles and the classical era Spartans distrusted it. Though, it had been kept in high respect and its use was far from forbidden in serious warfare. There was a full tactical and technical doctrine, as both documentary and representational sources inform us. It was never the choice of the rank and file, as it had been in other cultures, or as was the spear/javelin in the Greek world, but it was neither ignored nor despised as much as the sources directly imply. It was respected and feared and, when conditions both permitted and demanded, its use was acceptable, massive and quite successful. 


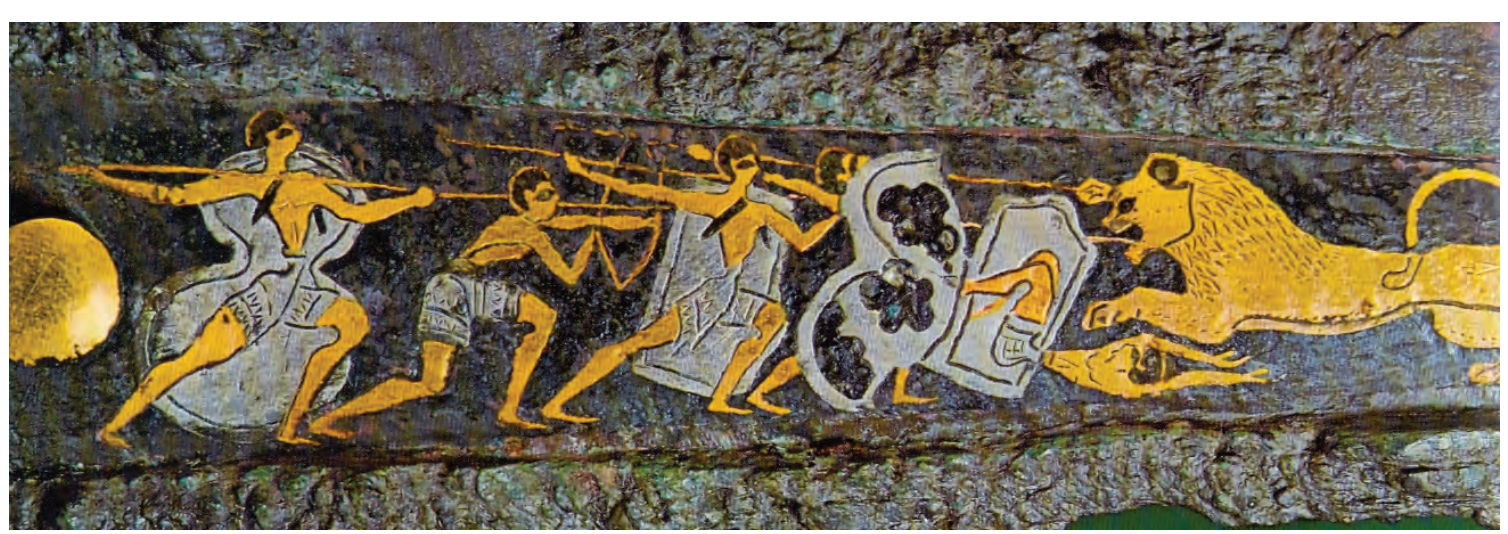

Fig. 1 Mycenean Archers are combined with body-shield infantry from the "Lion hunt dagger".

Copyrights: Wikipedia commons.

\section{THE DOCUMENTARY EVIDENCE}

First period:

\section{the Bronze Age and the heroic ethos}

Starting from Hercules, son of Zeus proper (Hes. Sh. 52-56 \& 103-105) and demi-god and hero par excellence in the Greek lore, he is an exiled prince whose scheming parents are banned from Tiryns (Hes. Sh. 80-81), when they claim rights to the throne of Mycenae. They find asylum in Thebes (ibid) after Oedipus (Hes. Sh. 83) and Hercules is champion of the city (Hes. Sh. 103-105). Hercules lives at the highlands off Thebes for quite sometimes and links to mountaineers and hill people and spends much of his life in mountainous terrain.

Hercules is mentioned to shoot at point targets with great accuracy and at extended range. The hero was immensely strong and widest of stature, which directly implies a powerful bow; his arrows, after a point in his career, where venomous, painted to the venom of the Hydra. He is rarely mentioned as armed in the proper, heroic way with conventional arms and armor (Hes. Sh. 122-138). Instead, he wears a lion skin and uses a club or a mace. His bow is passed to his follower Philoktetes who kindled his funeral pyre.

This picture of Hercules is very informative if compared to some figures described in the Iliad. There, the bow is despised by the Greek heroes, but not of the high command. There are two ar- cher contingents and four renowned archers in the Greek force. First is Philoktetes, the follower of Hercules, who leads an archer contingent numbering 350 men in seven 50-oared ships (Hom. Il. II$718 / 20$ ). Odysseus, the most prominent of stature (and perhaps the best known archer), does not lead an archer contingent. He has not brought his weapon, which is at least two generations old, almost the age of the one of Hercules. It is a gift from a previous renowned archer (Ifitos), friend to Odysseus (Hom. Od. xxi-25/30) and Odysseus never carries it in war (Hom. Od. xxi-39/41). The weapon has definitely wooden parts, as in Odyssey the owner inspects the weapon before bracing it to ensure that it is not compromised by woodworm (Hom. Od. xxi-394/6). The weapon shoots extremely straight; so straight that the arrow passes through the holes of 12 axes (Hom. Od. xxi-75/7). No matter which holes are implied, the 12 axes take a minimum of $1 \mathrm{~m}$ to be put, which means the arrow would drop $10 \mathrm{~cm}$ or less in trajectory for a span of more than $1 \mathrm{~m}$. He also possesses poisonous arrows, just as Hercules did, having imported the venom from north-western Greece, from the up-to-know mysterious Tafians (Hom. Od. i-260/5). His bow is very difficult to brace without deep knowledge of its secrets: everybody else fails, but he himself does so with minimal effort (Hom. Od. xxi-410), showing it was a matter of technique, not of strength and most probably concerns a recurve bow. It is an important issue that Odysseus had been very afraid of the Suitors getting proper body shields when 
trapping them, which means he doubted for the penetrating power of the weapon (Hom. Od. xxii146/8): Indeed, in the Iliad we read of no arrows piercing shields and wounding the carrier, which is not the case with spears.

Teukros is the most efficient archer in Iliad from the Greek heroes. He is no leader, but the brother of one. He is adept with spear and shield and reverts fast to them whenever needed (Hom. Il. XV478/82). He possesses no famous bow, but he is adept in fighting in conjunction to his brother Ajax, taking refuge behind his large shield before and after shooting his arrows with excellent accuracy in direct aiming (Hom. Il. VIII-265/72) [Figure 1].

Meriones, the Cretan, no 2 in command of its contingent, is a much acclaimed warrior with shield and spear (Hom. Il. XIII-255/8) and owns and operates a chariot (Hom. Il. XXIII-351). He only shoots at one instance during the fighting in the Iliad and this to a fleeing opponent (Hom. Il. XIII-650); though, he outdoes most lethal Teukros in an archery contest shooting at a pigeon (Hom. Il. XXIII-870/6). His bow is also nothing worthwhile-or, at least, nothing is mentioned. He uses it also when on guard duty and lends it to Odysseus for his scouting mission, along with helmet and sword (Hom. Il. X-260/1).

Last is the contingent of Ajax the Lesser, 40 ships full of archers (numbering up to 2000). They are explicitly mentioned to carry no armor and to shoot from behind friendly lines (Hom. Il. XIII$716 / 22$ ). They are thus very much accomplished in shooting indirectly and massively- in high arc. Their leader, though, is no archer; he is a very good and kinetic warrior with light armor but excellent in spearfight (Hom. Il. II-529/30).

The combined picture is that there was an era of great archers who were also the greatest of heroes (Ifitos and his father Eurytos are mentioned as such but relevant lore is lost to us). This era was less civilized, definitely rural and the best warriors were not armored but clad in skins, as Roman Velites; light, independent, on foot and wielding powerful hand-weapons for close-in. At that time a respectful weapon was the mace or club, either as stand-alone (Arithoos at Hom. Il. VII137/41) or as adjacent to bow (Hercules). These hero archers had no hesitation or restrains to the use of poison. But this culture of the bow was a thing of the "past" within the Achaean heroes of the Iliad, the bow was considered unheroic and uncivilized (Odysseus never brought his bow in war: Hom. Od. xxi-39/41) although tactically useful (second-best warriors used it, as did rank-andfile in some contingents). Trojan nobility, though, persisted with the bow in skill, form, function and mentality, but they also avoided the use of venomous arrows.

Paris, on the Trojan side, is adept with armor shield and spear, but when shooting his bow, he does so while hidden, in a sniper approach (Hom. Il. XI-379). In his first battle appearance he brandishes bow and spears but has no armor and gets from his brother Lykaon when he is challenged to duel (Hom. Il. III-332/3). Paris appears in leopard skin, bearing bow, sword and spears (Hom. Il. III15/18), thus reminding of Hercules, a person hated and despised in Troy. Consequently, the similarity of the appearance must imply not an aspiration of the heroic past, but the existence of a category of warriors, lightly armed for missile warfare with bow and hand weapon (Paris opts for sword, Hercules for club/mace) and clad in skins. Dolon, a Trojan scout, captured by Greeks, is armed with bow and spear and is dressed in wolfskin (Hom. Il. X-333/6). Odysseus, in his one and only appearance as an archer in the Iliad, has taken from Meriones bow, quiver, helmet and sword for his scouting mission (Hom. Il. X-260/1).

Paris' brother Helenos shoots his arrows while in a melee (Hom. Il. XIII-580/96), he bears full armor and reverts to sword for close combat (Hom. Il. XIII-576/7). But the most prominent archers are Pandaros from Lycia (Hom. Il. V-172/3), belonging to a contingent which fights conventionally, and the Paionean contingent, composed of archers (Hom Il. II-848), although their leader is killed in close combat. 


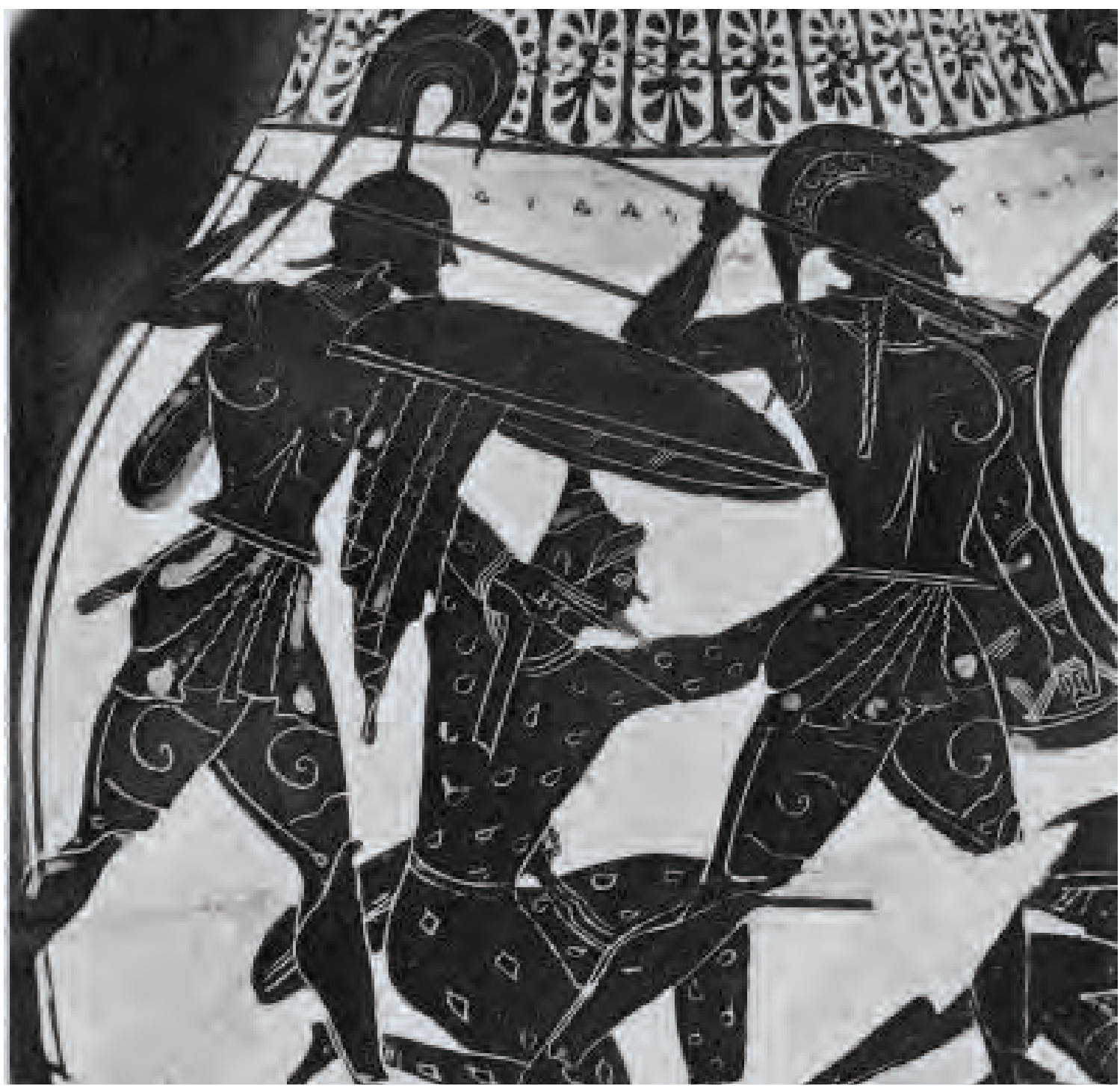

Fig 2: "Parentaxis": a Scythian archer, with gorytos and at a semi-kneeling position. fires covered by the shields of hoplites . Copyrights : Munich, Antikensammlungen Collection (550-500 BC)

The mentioning of bow in the Iliad is usually in the plural, meaning bows consisting of two parts. The bow of Pandaros is made of horn (Hom. Il. IV-109), which rather implies a bow consisting also of horn parts. His arrow is feathered, irontipped and rather short (Hom. Il. IV-123). The rear of the shaft is carved to forestall fingers slipping due to blood or sweat (Hom. Il. IV-122) and pierces three plates of armor when wounding Menelaos (Hom. Il. IV-133/5). It is important to remember that the armor of Menelaos staves off an arrow shot by Helenos from point-blank range (Hom. Il. XIII-585) -and Helenos, a prince royal, is not supposed to have an inferior weapon.
In the Iliad the bow is carried either hung from the shoulder (Hom. Il. X-333), straight or diagonally; it may also be carried in a holster, as Pandaros', but this is separate from the quiver (Hom. Il. IV105, Hom. Il. IV-116), in stark difference with the Scythian Gorytos which is a later invention.

\section{Second period;}

\section{the Archaic Era 8th-6th centuries BC}

The successors of Hercules, the Dorians, overwhelmed central and southern Greece after a famine all the way to Crete (Hdt VII.171). They developed the warrior culture of Dorian Sparta, 
hating the bow (Thuc IV.40,2), and the culture of Dorian Crete, embracing it more than any other area in Greece. The Dorian Spartans hire Dorian Cretan archers in their $9^{\text {th }}$ or $8^{\text {th }}$ century first war against fellow Dorian Messenians (Paus. 4.8.3) embracing the bow operationally and spawning the mercenary culture for the first time in this Greek era-and creating the Cretan archer-mercenary, an archetypal figure. These archers are deployed "behind the heavy infantry, in the Ancient way”, (Paus Mess 8,12), reminding the deployment of Locrian archers (Hom. Il. XIII. 716-22).

\section{Third period: \\ the Classical era 5-4th centuries BC}

With the exception of local peculiarities as in Crete, the archers in Greek service are either imported foreigners (possibly Greeks from other areas, Cretans being the usual choice -Thuc VI.43), or natives developed in authoritarian regimes as internal security. The tyrant Polycrates of Samos has 1000 of them, (Hdt. 3.39) definitely Greeks and possibly (but not probably) Samians and Peisistratos of Athens a body of Scythians. Figure 2]. Irrespective of their origin they can integrate into a phalanx and shoot covered by the hoplite shield formation ("parentaxis", Figure 2), most probably from a semi-kneeled position. This concept is very near the previous Mycenaean (in the Iliad) -and Near Eastern- method of use. The Cretans serve, as mercenaries, against the Persians as excellently illustrated by P. Green in "The year of Salamis" and the Athenian democracy has quite a number of archers in $480 \mathrm{BC}$, to post 4 to each trireme (which means at least 720 men) according to the Stele of Troezen. It is very interesting that after Peisistratus there were none, in 490 BC in Marathon, to defend the city (Hdt. 6.112)! Cretans or Athenians, 300 of these archers (another 400 may be with the fleet) fight in $479 \mathrm{BC}$ in Plataea where they excel against the Persian cavalry (Hdt. 9.22) and they are the only missile troops worth of the name in the Greek side in number, skill and impact-so much that the Spartans request their assistance when under Persian arrow storm to fend off the attackers (Hdt. 9.60). The shooting of the horse of the persian cavalry commander implies a direct shot, which in turn suggests parentaxis within the elite hoplite unit and not epitaxis behind them, which allows only for indirect fire.

As the Scythians cannot be imported since 510 BC as the Persian Empire cut both land and sea routes to the Black Sea, these archers are Greeks and possibly account for the shielded and/or armored archers illustrated in art (Figure 3).This implies holding the bow at the left hand with also the antilabe of the hoplon shield. It is a cumbersome practice when used from standing position, but kneeling alleviates the problem as the shield may rest its rimmed edge on the ground. Half-kneeling is the standard shooting position for Scythians in Greek art (Figure 2) as horsemen with short bows feel their waist more comfortable than when standing. The Greek archers do not use the asymmetric Scythian bow, as there is no need to do so when on foot. They are depicted with both simple-curvature self bows ("Libyan bow”, Figure 5) and with composite, symmetric ones (Figure 3), but the disdaining for the weapon resulted in very few references and no description of such examples. Scythian asymmetric bows shown for heroes, as is Hercules (who was always on foot) are simply anachronisms to place a really powerful weapon of the day (or of the age) in the hero's hands. Still, the Greek bow is not very big, as is the longbow. Both Herodotus and Xenophon are impressed by long bows; the former in Persian hands (Hdt. 7.61) and the latter in Cardouchian hands (Xen. Anab. IV.3). Moreover, the Indian longbow made a lasting impression to Alexander's troops (Arr. Ind.16.6.6), but perhaps to their forefathers as well, since Indians were present in Xerxes' host (Hdt. 7.62).

In late Mycenaean frescoes from ancient Pylos, light infantry using small two-handled circular shields exist. These fit well with the bronze-covered small circular shields Xenophon says Cretan 


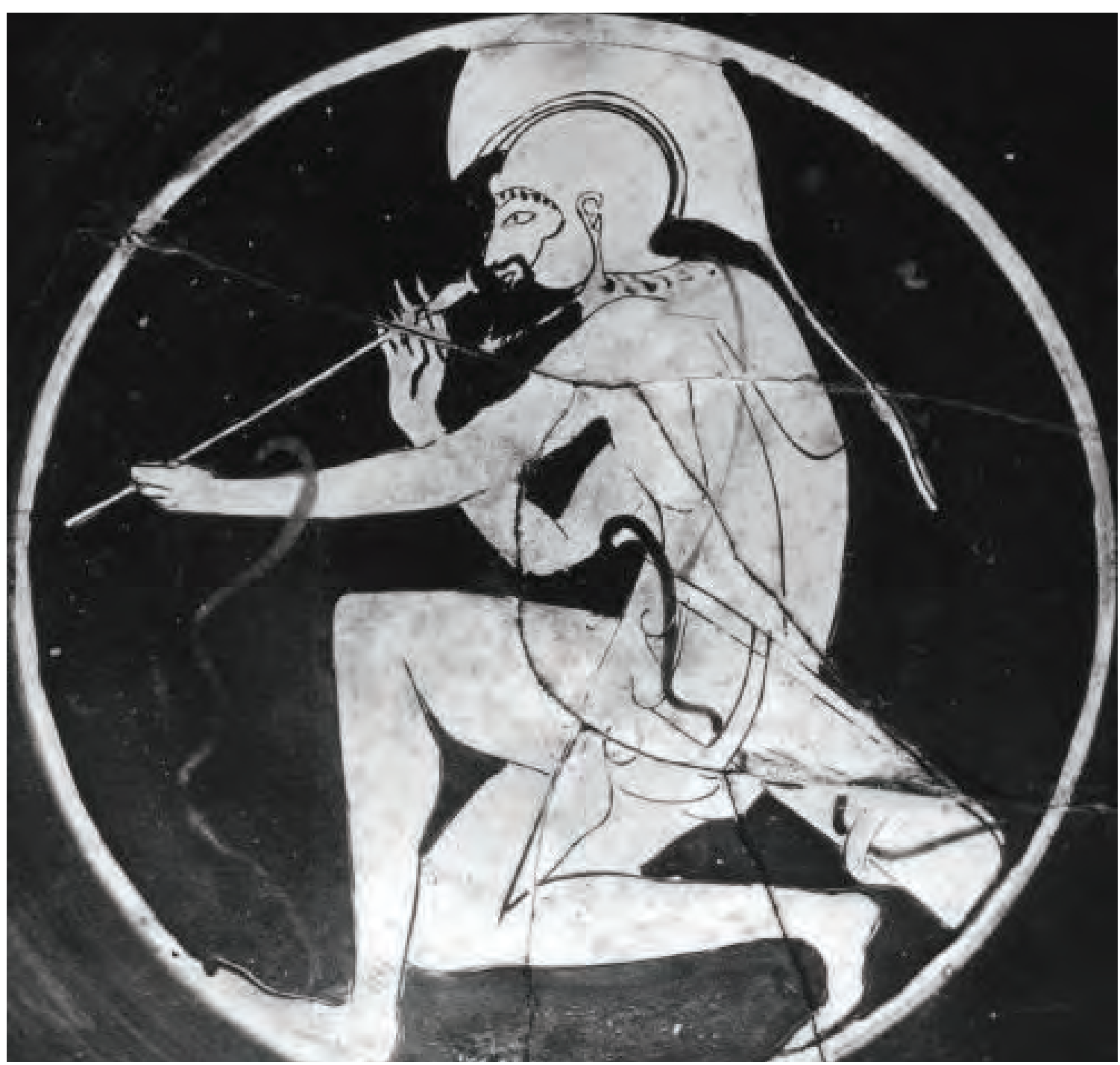

Fig. 3 Native Greek archers possibly account for the shielded and/or armored archers illustrated in art . Copyrights : London, British Museum (525-475 BC).

archers had (Xen. Anab. V.2.28-32), and there is no mention about them being rimmed or rimless; though the term proper means rimless. Xenophon, writing almost half a century before Aristotle (the latter classified the shields more definitely) never used the terms "hoplon"/"shield" and "pelte" inconsistently. With pelte shield, light, small and rimless, the holding of the bow when standing while having the shield at the forearm at the ready is easy. The shield is moved a bit up and the antilabe is at the wrist instead of the palm. As pelte shields always had belts to hang them at the back when fleeing, this was another option, although less practical in exchanging fire. But having the pelte at the forearm permitted a very fast shootshield cycle, clearly advantageous against unshielded archers in skirmish in broken ground or other kinds of non-set battles. A well-trained Cretan would use the time of covering-which brings the left hand and thus the bow near the center of the chest- to nock the new arrow to his bow and draw as soon as ready, cutting on the time and exposure. It is no accident that Thucydides says that in 424 BC the archers of the Athenian task force in Aetolia kept the local javelineers at bay over extra-rough terrain as long as they had arrows; then slaughter ensued (Thuc. 3.98,1).

Although our sources keep silence, there is no 
need to exclude lightly shielded archery for $9^{\text {th }}$ century Cretans in Spartan pay or $5^{\text {th }}$ century ones fighting against the Persians. The ability to combine with heavy infantry is also long-standing.

\section{Fourth Period:}

\section{The era and the army of Alexander the Great}

We have no record of arms, or armor of the archers of the army of Alexander. His main archer force are native Macedonians and mercenary and allied Cretans. The army of Alexander is not different from other Greek armies of the Era in any revolutionary way. But it incorporated so many evolutionary changes, both of his own and of other quasi-contemporary generals that the whole was revolutionary. We know a lot on archers' organization and operations. The tactical units are the 500men lochoi, and this is the probable strength of the archer arm when the expedition began, to climb to perhaps 2.000, half Cretan and half Macedonian (Arr. An. III.12) 3 years later-before large numbers of Asian natives are incorporated in the army. Their use is according to the late $5^{\text {th }}$ century Greek doctrine: not massive fire but mobile fire available in 3-D context and broken ground. They are supporting flying columns and special operations (i.e. in Arr. An. I.27 they are used for storming a mountain pass), being incorporated in every fast detachment/ task force led by Alexander to lightning action. They are used in support of shock troops in urban warfare and in siege, which ascertains their ability to fire fast, upstanding and on the move (Arr. An. I.1). They take casualties, especially if trapped by heavy opponent in limiting ground, as in Thebes, where they suffered a terrible blow when cornered by hoplites as the shock action they supported did not broke through, to allow them to burst into freer terrain and deliver volume fire (Arr. An. I.8). The most incredible is the casualty rate of the Master of Archers (Toxarchos), with three fatalities in less than 2 years (Arr. An. I.8 \& I.22 \& I.28), two in being in siege action (Arr. An. I.8 \& I.22), as they always support the storming parties. In set battle they are mingled with shock troops-especially heavy cavalry (Arr. An. IV.4) to offer fire support in a fluid and concentrated manner in time and space - or they are assigned to certain parts of the line to provide massive, concentrated counterfire against Persian archery (Arr. An. II.9). The distinction of their service and the way they are used shows a culmination of all previously spotted features and assets: mobility in terms of speed and negotiating difficult terrain, stamina, initiative, adaptability, ability to shoot fast and accurately and deliver a considerable volume of arrows in time- and space-sensitive conditions and resilience. These imply lack or lightness of armor, an array of arms (perhaps javelins and surely side arms such as swords/sabers), shield and possibly helmet, and the ability to shoot fast and accurately while standing and on the run-perhaps not while running, but stopping for a shot and then running again to a new position, like modern infantry in assault.

From that point, Greek archery is not evolved any further. The Diadochi outfit and train other Greek -and non-Greek also- stock as archers in the Cretan style, while incorporating native archers of the conquered nations, such as Jews used by the Seleucids along with Cretans or Cretan-type to suppress the revolt of the Antiocheans (Maccabees 11.45-47).

\section{DEFINING ATTRIBUTES OF GREEK ARCHERY}

\section{Drawing and shooting "from the hip": the skill of the elite in Mycenean-era archery}

In both sides of the Trojan War there is evidence of quickdraw skills. Helenos and Teukros shoot in a melee and face opponents who charge from close by. Instead of switching to sidearm as they could not rearm with spear and shield in a few seconds' time, they shoot arrows at their assailants but are unsuccessful and get injured. Helenos arrow is deflected by Menelaos' armor and he gets 


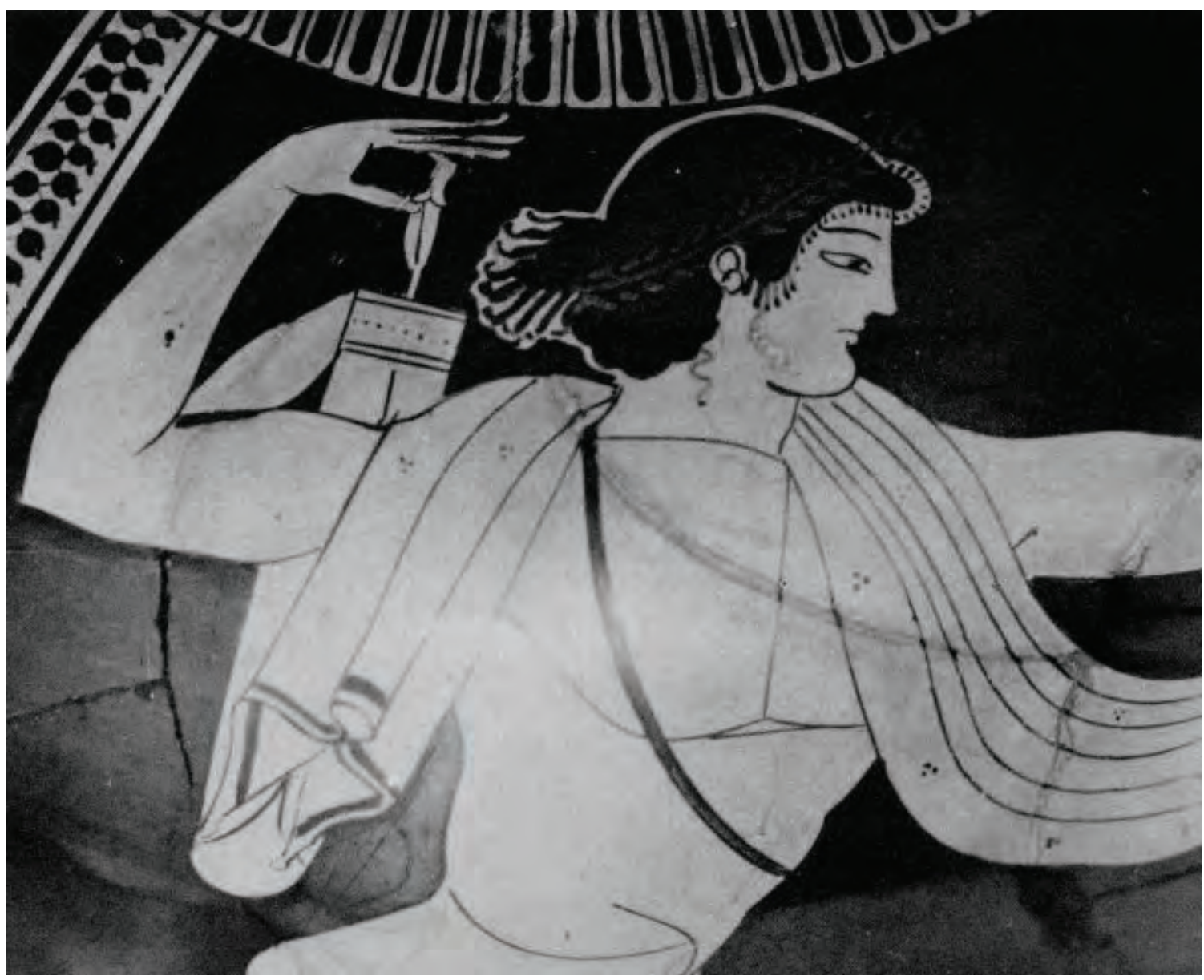

Fig. 4 The quiver in Greek practice is carried diagonally to the back and its opening (usually covered) is just behind the right shoulder. Copyrights : London, British Museum (500-450 BC).

injured at his hand by spearthrust (Hom. Il. XIII593/5), while Teukros is injured at chest by a stone (Hom. Il. VIII-320/30) before releasing his arrow. Meriones, when in an archery contest with Teukros has an arrow at the ready and grabs the bow from the hands of his competitor (in an obvious rule to use the same weapon to test skill only) and shoots immediately at the target pigeon (Hom. Il. XXIII-870/6) which was freed by Teukros erratic shot cutting the fabric that kept it confined (Hom. Il. XXIII-866). The procedure obviously does not allow for kneeling to assume shooting position.

\section{Precision Aiming by a master archer}

The important thing is that we know exactly how Pandaros shoots. Homer mentions that he is hiding behind friendly shields (Hom. Il. IV-114), which might imply semi-kneeing posture, which in turn means a rather short bow and thus impossible to make from the horns of a wild goat ONLY, as these are specifically mentioned to be much longer. That the bow is short we know for sure since Pandaros draws both arrow and string (Hom. Il. IV-122), and only to the chest (Hom. Il. IV-121/3). This most probably implies to the chest at the side of the bow, a mere palm longer than his extended arm. At this draw, the arrowpoint was touching the bow proper, meaning this was the maximal draw. In such a case one cannot shoot with accuracy by aiming along the arrowshaft, as it is too low. Thus, the aiming was probably accomplished by boresighting the point to the target and keeping the shaft straight under. The distance was calculated empirically to define the elevation. This high-head aiming is seen in later statues and 


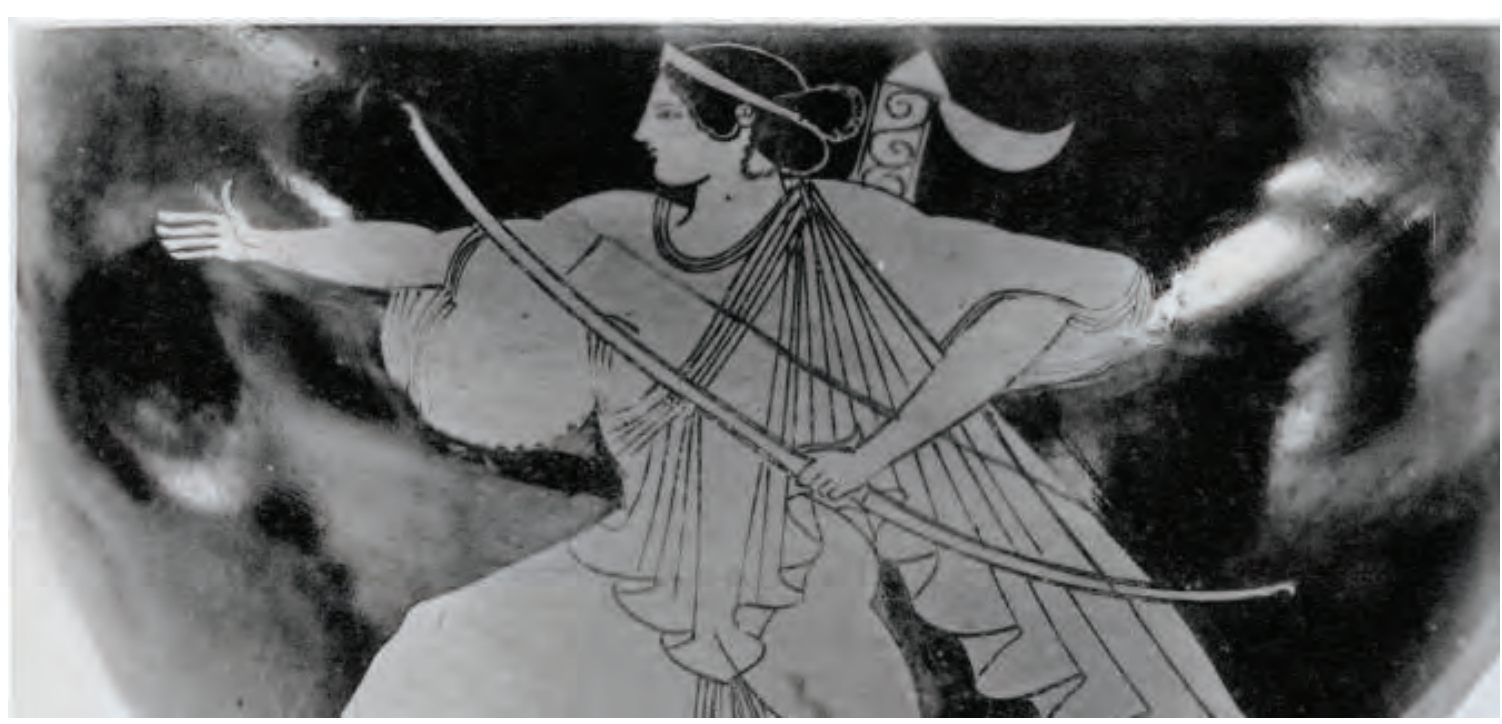

Fig. 5 Depiction of a self bow ("longbow") in the hands of Artemis.

Copyrights : Madrid, Museo Arqueologico Nacional (500-450 BC).

paintings and is very different to the longbow direct aiming along the shaft (which is drawn to the ear) as used by Welsh, English, far-easterners and perhaps Persians as well.

\section{The novel use: manoeuvre as force multiplier}

The interesting point is that at the 5th century the archer contingents are not missile troops firing en masse, but light troops using motion, maneuver and fluidity in the battlespace, and perhaps able to shoot almost on the move (a skill perhaps inherited from their Mycenaean forefathers as noted before). The novelty is that the maneuver here is limited in speed but extended to a third dimension in rough terrain, an issue never tackled by all previous and contemporary archer cultures which combined the missile power of the bow with cavalry, either chariot or horse and/or camel and elephant versions of the cavalry arm.

In the Greek mobile archery, shooting is direct and the arrows are small; Cretan archers in 400 BC fire spent Persian arrows back by shooting high, in indirect mode because these arrows were too big for their bows (Xen. Anab. III.4.16). This shows a high degree of experience, skill, initiative and adaptability; it also tells about the superiority of the Persian bow in range, as witnessed and attest- ed by Xenophon himself (Xen. Anab. III.3). The high-arc shooting is mentioned as something unusual and exceptional, showing the limited range of either the standard Greek archery or the knowledge of a professional soldier on this subject.

The novel use of the archers is a complicated issue. The expeditionary warfare undertaken by the Athenians needed specialist troops to operate far, in unknown terrain and for indefinite periods, as sieges had no seasonal limitations. This turn in events started from the effort to expel the Persians from European soil but went on to all civil wars Athens caused later on. Scythians were reintroduced in 446 BC (Andoc. 1 Oration 3.5), and in $434 \mathrm{BC}$ a decree was issued to both civic and alien archers. Cretan archers, in small numbers, are among the other archers sent in Sicily in 415 BC (Thuc. VI.43), evidently to offer capabilities unavailable to other archers in Athenian roster most probably the shielded foot-archery skill. In the same context, after the Pylian Disaster of 425 BC, Spartans reintroduced archers (and cavalry) to fend off Athenian raids from Pylos and rebel Helot encroachments (Thuc. IV.55). Western Greeks, in Sicily and southern Italy used archery in both native and mercenary alien forms, without leaving any record on the modus operanti, organization, skill and equipment. 


\section{CONCLUSIONS AND SUGGESTIONS}

The hoplite ideal, followed by the agrarian society, drives the tiny Greek communities away from the archer. The hoplite is the best choice to colonize the Mediterranean with few ships, manned with few colonists and sent everywhere but in tiny numbers per place. It is also a better choice to impose oligarchies or to fight in a strict framework of Justice-in-war with their neighboring communities and, in general, to occupy and hold terrain-which is vital for food and feed production. To save horse and extend virtue, the bow is prohibited in some set-piece battles to allow hoplite skill to show, while its construction is expensive and tricky and mastering it demands time and practice ill-afforded by the agrarian (farmer) or bourgeois (such as craftsmen) part-time warriors. Its exclusion is a matter of choice. Archery is a tricky discipline and it needs constant and hard practicing to acquire skills and keep them honed. But the same is with hoplite gear. Hoplite gear is expensive, but it became more affordable for the civic body than the middle-age panoplies ever were. Being a hoplite was very tricky, but the essentials were attainable with some hard but short practice, in a year of mandatory service in $4^{\text {th }}$-century Athens. But the essentials of the archery are just as easy to learn, and the weapon is by no means more expensive than standard hoplite gear. Greece is a land excellent for pasture, to acquire the raw materials for bows of the best quality. The Greeks simply preferred the spear. It is obvious that the few communities which chose differently (Crete for example) had no difficulty in producing excellent archers and descent weapons, as did much poorer areas throughout history, such as the steppe. In this framework, the Greek archery survived discretely and flourished in its second youth with the advent of comprehensive and integrated multi-arm expeditionary forces able to operate in difficult terrain. The Cretan large arrowheads, so reminiscent of the ones English longbowmen used against horses, imply evolution and aadaptation. The striking similarities in form and weapons in an unbroken succession of representational evidence spanning 900 years, show the continuity and nativeness of the important though uncelebrated Greek archery tradition.

\section{BIBLIOGRAPHY}

\section{Ancient Sources}

Arrian, Anabasis

Andokides, Oration 3.5

Diodorus Siculus, Library

Herodotus, The Histories

Homer, The Iliad

Homer, Odyssey

I Maccabees

Pausanias, Description of Greece

Plutarch, Camillus

Plutarch, Moralia, Sayings of Kings and Commanders

Thucydides, History of the Peloponnesian War

Xenophon, Anabasis

\section{Contemporary Scholarship}

Anderson, J. K. 1970

Military theory and practice in the Age of Xenophon, Berkeley: University of California Press.

\section{Bar-Cochva, B. 1979}

The Seleucid Army: Organization and Tactics in the Great Campaigns, Cambridge: Cambridge University Press.

\section{Bakas, S. 2014}

The shooting methods of the archers of the Ancient Greek World 1400 BC-400 BC, The National Association of Archery for all Organization (WTAF, Cheonan City, Chungnam-do, Republic of Korea. 


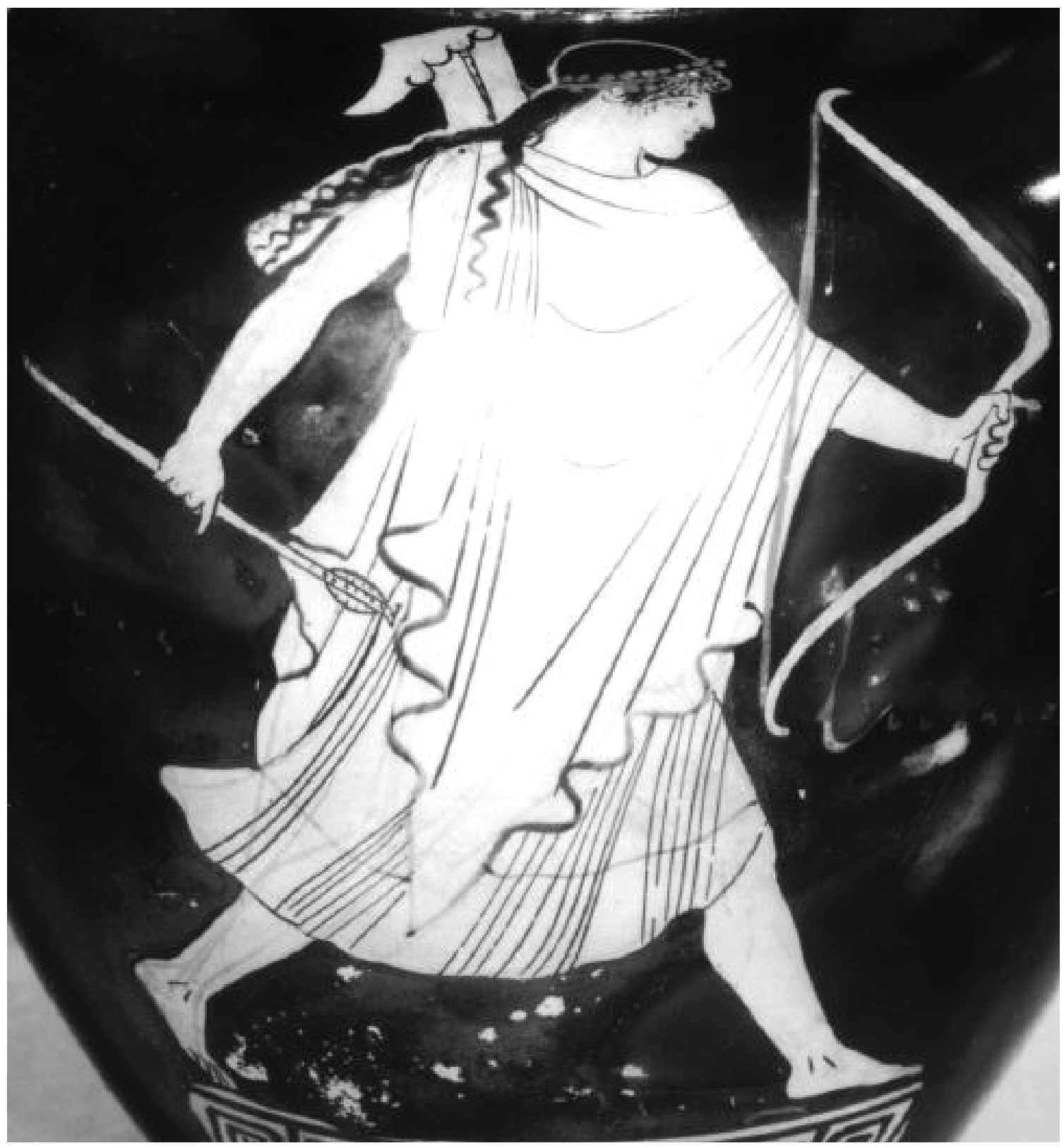

Fig. 6 Asymmetric bow of the Scythian type.

Copyrights : Paris, Cabinet des Medailles (500-450 BC).

Bakas, S. 2016

Composite bows in Minoan and Mycenaean warfare”. Syndesmoi (4) 2016, Sympozjum Egejskie. Proceedings of The 2nd Students' Conference in Aegean Archaeology: Methods - Researches Perspective, Institute of Archaeology, University of Warsaw, Poland, April 25th, 2014. Quaderni del Corso di Laurea in Archeologia, opzione internazionale, Università degli Studi di Catania.

\section{Bradford, A. S. 2001}

With arrow, sword and spear, Praeger Publishers.

Davis, T. A. 2013

Archery in Archaic Greece, PhD Dissertation, Columbia University.

\section{Green, P. 1970}

The year of Salamis, Weidenfeld \& Nicolson Press. 
Hackett, J. 1989

Warfare in the ancient world, London: Sidgwick\& Jackson Press.

Mayor, A. 2008

Greek Fire, Poison Arrows and Scorpion Bombs:

Biological \& Chemical Warfare in the Ancient

World, New York: The Overlook Press.

\section{REZIME}

STRELIČARSTVO U ANTIČKOJ GRČKOJ: OPERATIVNA PRAKSA I TAKTIKE

KLJUČNE REČI: STRELIČARSTVO, ANTIČKA GRČKA, BRONZANO DOBA, ARHAJSKI PERIOD, KLASIČNI PERIOD.

Ispod vela magle pomalja se pitanje drevnog grčkog streličarstva, jer se u prošlosti smatralo nepouzdanim i neprimerenim principima časne borbe. Uprkos tome bilo je cenjeno. Postojala je cela taktička i tehnička doktrina, o čemu svedoče predstave i pisani izvori. Još je za Herkulesa, Zevsovog sina, koji je smatran pravim i polubožanstvom i izvanrednim herojem u grčkoj mitologiji, spomenuto da je gađao udaljene mete sa velikom preciznošću i da je to činio sa otrovnim strelama. Drugi poznati streličari iz ove ere su Odisej i Paris, koji se iako nije bio Grk, u tome najviše istakao; pominju se tako čitave jedinice streličara koji gađaju preko prvih linija prijateljskih formacija. Nakon ovog perioda kada su i plemstvo i vojnici bili obučavani za korišćenje luka i strele, klasični Grci koriste streličare kao živi zid. Njih je malo i uglavnom su ih regrutovali ili dovodili iz stranih zemalja tirani i ostali omraženi vladari. Iako je ta veština prezirana, u čitavim oblastima ona se razvijala i ukorenjivala u njihovu kulturu. Ovo oružje se koristilo sa hirurškom preciznošću protiv istaknutog streličarskog napadača, Persije, sa poražavajućim efektom i na kopnu i na moru. Tehnike gađanja i taktike iz tog doba podrazumevaju direktno nišanjenje, ali se i indirektno ciljanje visokim lukom takođe pominje nekoliko decenija kasnije kao poznata veština. Do Aleksandrovog doba, standardna doktrina koja uključuje male, ali odabrane streličarske snage (gubi svoje komandante tri puta za tri godine) ukazuje na njihovu efikasnost u manevarskom ratu na teškom terenu i u posebnim operacijama. 